\title{
Research on Teaching Reform of Military Course in Universities from the Perspective of Training Innovative Talents
}

\author{
Shanhua Luo \\ Military Teaching and Research Office \\ Harbin Institute of Technology \\ Harbin, China
}

\author{
Gongchen $\mathrm{Su}$ \\ Military Teaching and Research Office \\ Harbin Institute of Technology \\ Harbin, China
}

\begin{abstract}
Teaching reform of courses must establish student-oriented and teacher-guided teaching idea, in order to promote students' independent study and personality development through scientifically setting courses, optimizing teaching contents and highlighting basic structures and characteristics of courses meanwhile make it basic and advanced, classic and innovative, systematic and practical. Reform of teaching methods is strengthened to train students' ability in finding, analyzing and solving problems. In teaching reform of military course, it is of vital importance to strengthen scientific research awareness and ability of teachers of military courses and improve their professional level.
\end{abstract}

Keywords-innovative talents; military course in universities; teaching reform

\section{INTRODUCTION}

Innovative talents are the most important strategic resources in the world. The cultivation of innovative talents has become important strategic measure for countries to achieve economic development, scientific and technological progress and improve international competitiveness. Innovative talents are talent training objective proposed under new historical background. Innovative talents have innovation consciousness, innovation ability and international view and global consciousness. Military courses in universities are important part of Chinese higher education. Its property and training objective conforms to training objective of innovative talents. Just as the description of Military Course Syllabus in Universities issued by the Ministry of Education, "Military courses are required courses of undergraduates and junior college students. According to the requirement that education must be modernized, international exposure and face the future, meet the demands of strategic objective of talent training and strengthening the construction of reserve forces for national defense to train high quality builders and defenders of socialist cause [1]." To adapt to innovation education and training objectives of innovative talents, teaching reform of military courses in universities must update teaching idea, optimize teaching contents and improve teaching methods as well as construct new system of course teaching, in order to continuously promote the teaching reform of military courses in universities.

\section{UPDATE TEACHING IDEA AND CONSTRUCT NEW SYSTEM OF COURSE TEACHING AND HIGHLIGHT NEW CHARACTERISTICS OF TEACHING}

In new period, the core of higher education is innovation education, in order to train innovative talents. Scholars and experts think we must reform teaching models, educational objectives, course system, management system and construction of teaching staff, and train students' innovation consciousness and ability to make excellent talents stand out.

\section{A. Establish New Teaching Idea of Military Course}

The source and foundation of innovation is individualization of talents. We must establish new teaching idea of military courses: establish student-oriented and teacher-guided educational thought to promote students' independent study and personality development. Teaching idea must embody the cultivation of students' knowledge, ability and quality especially innovation ability. Teaching management system must be improved. At present, universities implement the credit system, so do military courses. It requires credit system is not only a teaching management system but also embodies the student-centered theory on school management that gives sufficient freedom of study for students. Respecting students' interests helps to develop students' individuality. Interests and individuality are premise of innovation. Meanwhile, strengthen the management of teaching process and avoid cramming for a test and fully arouse students' enthusiasm in independent study.

\section{B. Build New Teaching System of Military Courses}

Course system is the division of labor and coordination between courses in one specialty. The rationality of course system directly concerns the quality of talent training. Optimization and reform of course system must closely surround teaching objectives, closely connect contents and conform to talent training law and objective law of education, at the meantime reflect systematic course and contents. The 
fundamental goal of military course is to improve military accomplishment and comprehensive quality of students. The purpose of teaching activities and the systematic implementation of teaching determine systematic and comprehensive course system and teaching contents.

\section{Highlight Systematic Teaching of Military Courses}

Military courses involve various military subjects, the contents of which connect and form integral course system. According to the current requirements of Outline issued by the Ministry of Education, teaching contents of military courses in universities constitute military skill training and the teaching of military theory. Military skill training includes: education on regulations and training, light weapon firing, tactics, military topography and integrated training. Teaching of military theory includes: military thoughts, China's defense, international strategic environment, military high technology and information war. Contents of these courses closely surround teaching objectives and cover basic knowledge of military theories and basic military skills that college students should grasp. Therefore, course provision should be systematic.

\section{Highlight Comprehensive Teaching of Military Courses}

From the perspective of systems engineering, universities must analyze and integrate teaching contents of military courses and establish comprehensive courses in military subject. Main courses of basic theories like military thoughts, China's defense, international strategic environment, military high technology and information war must be innovated. Latest military theories are used to solve significant problems in national defense construction and military struggle. Seek breakthrough on practice of military theory and arouse students' enthusiasm in analyzing realistic problems. Increase the proportion of teaching military courses of contemporary China and form characteristic courses such as ancient military thought of China and Mao Zedong military thought [2], to make college students comprehensively, systematically and thoroughly grasp core system of military theories of leaders of Chinese Communist Party and let them develop overall consciousness and improve ability consciousness. Therefore, course provision should be comprehensive.

\section{DEEPEN REFORM OF TEACHING MODEL, OPTIMIZE} TEACHING CONTENTS AND IMPROVE TEACHING METHODS

Transformation of teaching model is the key to improve teaching quality and train students' innovation ability. Educational environment determines educational quality. In design of training model, attentions must be paid to students' independent study and innovation ability. Teaching systems like military theory teaching, military skill training and sports activities of national defense are built through providing courses related to national defense education, in order to transform teaching model of knowledgetransference into innovation-based teaching model. Specifically, it is to optimize teaching contents and improve teaching methods.

\section{A. Deal with the Relation between Basic and Advanced Teaching Contents}

Teaching object of universities is young students growing up in peacetime. They know little about military theories, so it is of vital importance to teach them modern military theories and traditional military culture at all times and in all over the world. It refers to basic education for students to grasp knowledge of modern military science. Advanced courses must keep up with new requirements of development of times and bring the world's hot military issues, the latest information and frontier problems in teaching contents.

\section{B. Deal with the Relation between Classic and Innovative Teaching Contents}

Military courses depend on military science and its teaching contents cover all aspects of modern military science. Universities must optimize classic teaching contents, expand edificatory and innovative talents and elaborate new theories with new knowledge and strengthen students' innovation consciousness.

\section{Deal with the Relation between Systematic and Practical Teaching Contents}

At present, teaching contents of military courses constitute military skill training and the teaching of military theories. Teaching of military theories must be systematic. The nature of theoretical teaching contents must be highlighted. At the meantime, according to the demands that teaching contents must teach rich theoretical knowledge and train manipulative ability, importance must be attached to the relation between skill training and theoretical teaching, in order to train students' ability.

\section{Intensify the Reform of Teaching Methods and Advocate Heuristic Education}

From the perspective of modern teaching theory, in order to train students' ability in finding, analyzing and solving problems, modern educators advocate heuristic education and problem-based teaching. Correct application of these teaching methods can improve students' quality, strengthen their learning interests and arouse their subjective initiative and train their innovation ability. In teaching, we teach around problems, stimulate students to think consciously and explore actively and guide them to find, propose, analyze and solve problems continuously, in order to train their creative thinking.

\section{STRENGTHEN TEACHERS' CONSCIOUSNESS OF SCIENTIFIC RESEARCH AND IMPROVE THEIR INNOVATION ABILITY TO PROMOTE THEIR DEVELOPMENT}

Universities are cradle of scholars and scientists. In the era of knowledge economy, universities are base of talent training and assume the important missions of knowledge innovation and technological innovation. In order to adapt to innovation education and train innovative talents, teachers must have ability of knowledge innovation. Teachers of military courses must teach and participate in scientific research, update knowledge and strengthen ability in 
scientific research and improve academic level. It is the key to teaching reform of military courses.

\section{A. Strengthen Scientific Research Consciousness and Ability of Teachers of Military Courses}

Scientific research consciousness means teachers of military courses actively explore phenomena and problems in teaching military courses and educational field, and keep occupational sensibility and the desire of exploration. Teaching and scientific research are two tasks of university teachers. The combination of teaching and scientific research means mutual promotion. For example, teaching difficulties in reform of course construction are scientific research tasks. Teachers of military courses have to improve teaching quality, integrate teaching with scientific research and ceaselessly improve ability in teaching and scientific research and independent innovation. The foundation of scientific research can train innovation ability and level of teachers of military courses in scientific research, as well as their innovation consciousness. [3]

\section{B. Improve Professional Level of Teachers of Military Courses}

The main problem that restricts the development of scientific research of teachers is that military courses in universities haven't formed professional system and have slow discipline construction. Therefore, discipline construction of military courses must be accelerated to train professional talents and improve professional level of teachers of military courses. Discipline construction provides legal identity and sense of belonging for teachers and provides more space for scientific research, in order to guarantee stability and enthusiasm of teachers in military courses on career development and keep sustainable development of construction in military courses. [4] The improvement of teachers' professional level can refer to training mode of teachers in other disciplines and specialties. The deployment of teachers of military courses must depend on their characteristics and refer to job requirements of other teachers, adhere to the principle of possessing both political integrity and ability, in order to improve professional level of them.

\section{CONCLUSION}

According to the requirement of development of times for talent training, universities aim at training talents, especially innovative talents. The improvement of talent training and the cultivation of innovative talents must deepen teaching reform and innovate in teaching models. Therefore, it is necessary to accelerate the teaching reform of military courses in universities at present and in the future, in order to meet requirements of the training objective and the model of talent training.

\section{REFERENCES}

[1] Ministry of Education, the Headquarters of the General Staff, the General Political Department, Military Course Syllabus in
Universities (2016 Revision) [M], Beijing: Issued by the Ministry of Education, 2007: 2-4

[2] Teaching Coordination Center of Military Training for Students in the Whole Army, Collected Papers of Teaching Seminar of Military Training for Students in the Whole Army [G], Beijing: Issued by Teaching Coordination Center of Military Training for Students in the Whole Army, 2005: 78-79

[3] Liao Wenke. New Theoretical Perspective [M], Beijing: Higher Education Press, 2006: 403-404

[4] Liao Wenke. Collected Papers of the 5th National Defense Education Seminar in Universities [M], Beijing: Higher Education Press, 2011: 4-6. 